\title{
Conservatism of earnings reported under International Accounting Standards: A comparative study
}

Juan Manuel García Lara, Juan Antonio Rueda Torres \& Pablo J. Vázquez Veira

To cite this article: Juan Manuel García Lara, Juan Antonio Rueda Torres \& Pablo J. Vázquez Veira (2008) Conservatism of earnings reported under International Accounting Standards: A comparative study, Spanish Journal of Finance and Accounting / Revista Española de Financiación y Contabilidad, 37:138, 197-210, DOI: 10.1080/02102412.2008.10779642

To link to this article: https://doi.org/10.1080/02102412.2008.10779642

曲 Published online: 15 Jan 2014.

Submit your article to this journal $\pi$

山 Article views: 65

47 Citing articles: 5 View citing articles ๔ 


\title{
Conservatism of earnings reported under International Accounting Standards: A comparative study ${ }^{*}$
}

\section{Conservadurismo del resultado contable bajo las Normas Internacionales de Contabilidad: Un estudio comparativo}

Juan Manuel García Lara ${ }^{* *}$. Universidad Carlos III de Madrid Juan Antonio Rueda Torres. Universidad de Sevilla

Pablo J. Vázquez Veira. Universidad de Alicante

\begin{abstract}
In this study we analyse whether the use of IASB standards affects the conservatism of earnings of the firms that adopt them. We compare the conservatism of firms by groups of firms/countries using or not IAS. Our results show that 1) Earnings conservatism is, as pointed out in prior research, more pronounced in common-law-based developed economies; 2) The voluntary use of IASB standards in Europe (prior to 2005) has significantly increased the measures of earnings conservatism in adopting firms, and 3) The use of IAS fails to improve the relevance and reliability of accounting information in emerging/developing countries, where enforcement and investor protection is low.
\end{abstract}

KEYWORDS Earnings properties; Conservatism; Accounting Standards, IASB.

RESUMEN En este trabajo se analiza si el uso de las normas del IASB afecta al conservadurismo del resultado de las empresas que las adoptan. Para ello comparamos el conservadurismo por grupos de empresas/países que usan o no las normas internacionales (NIC). Nuestros resultados muestran que: 1) El conservadurismo del resultado es, tal y como pone de manifiesto la literatura previa, más pronunciado en los países desarrollados basados en el derecho común, 2) La adopción voluntaria de las normas del IASB en Europa (antes de 2005) aumentó significativamente las medidas de conservadurismo del resultado de las empresas que las adoptaron, y 3) El uso de las NIC no logró mejorar la relevancia/fiabilidad de la información contable en los países emergentes o en vías de desarrollo, donde la protección de los intereses de los inversores es escasa.

PALABRAS CLAVE Propiedades del resultado; Conservadurismo; Normas Contables; IASB.

\section{INTRODUCTION}

In this study we analyse whether earnings conservatism (bad news recognized in earnings on a timelier basis than good news) of firms using IASB standards differs significantly from

\footnotetext{
* The paper has benefited from presentation at the 2007 AECA meeting (Valencia, Spain). We acknowledge financial contribution from the Spanish Ministry of Education and Science (SEJ2005-08644-C02-01/ECON and SEJ2007-67582-C0202ECON).

** Address for correspondence: Juan Manuel García Lara. Universidad Carlos III de Madrid. Department of Business Administration. C/ Madrid, 126B. 28903 Getafe (Madrid). Spain. Phone number: +34.91.624.8657. E-mail: jmglara@emp. uc3m.es
} 
earnings conservatism of firms using local GAAP ${ }^{(1)}$. Ball, Kothari and Robin (2000), Ball, Robin and Wu (2003), García Lara, García Osma and Mora (2005) and Bushman and Piotroski (2006) among others, argue that differences in conservative practices affecting the profit and loss account across countries are attributable to different institutional settings (for example, different litigation risk), and that the use of a common set of accounting standards will not contribute to reduce the differences in the properties of earnings if the differences in the institutional settings remain. In a similar vein, Ball et al. (2003) conclude that high quality standards do not guarantee high-quality financial reporting practices in developing/emerging countries without proper enforcement mechanisms.

The success of the implementation of IASB standards in Europe (and also in other countries) hinges crucially on whether the use of the standards will make accounting information more comparable, relevant and reliable. To analyse whether IASB standards are able to change the attributes of accounting earnings, we analyse the differences in the asymmetric timeliness of earnings (earnings conservatism) in 58 countries, comparing firms that use local GAAP with those that use IASB standards. We choose to analyse earnings conservatism because: 1) It has been shown that better governed firms report more conservative earnings as a response to investors demands (Beekes, Pope and Young, 2004; Ahmed and Duellman, 2007; García Lara, García Osma and Penalva, 2007, 2008a); 2) There is evidence showing that conservative earnings lead to positive economic outcomes such as an amelioration of the problems derived from information asymmetries between informed and uninformed investors (LaFond and Watts, 2008), better investment efficiency (Bushman, Piotroski and Smith, 2006; Ahmed and Duellman, 2008), improvements in contracting efficiency (Ball, Robin and Sadka, 2008), decreases in the cost of debt (Ahmed, Billings, Morton and Stanford-Harris, 2002; Vander Bauwhede, 2007); and in the cost of equity capital (García Lara, García Osma and Penalva, 2008b), and 3) Because conservatism in earnings differs substantially across accounting regimes and it has been shown to be one of the main international differences in the properties of accounting earnings (Pope and Walker, 1999; Ball et al., 2000; Giner and Rees, 2001; García Lara and Mora, 2003, 2004; Raonic, McLeay and Asimakopoulos, 2004; García Lara et al., 2005; Bushman and Piotroski, 2006; Gassen, Fülbier and Sellhorn, 2006).

Our results show that 1) Earnings conservatism is, as pointed out in prior research, more pronounced in common-law countries; 2) The use of IASB standards in Europe has significantly increased the measures of earnings conservatism in adopting firms, and 3) The use of IAS fails to improve the relevance and reliability of accounting information in emerging/developing countries. Our results are consistent with high quality accounting standards increasing the quality of financial information only if properly enforced and when appropriate corporate governance mechanisms are in place to protect investors.

The remainder of the paper is as follows: in Section 2 we analyse the reasons underlying the adoption of IASB standards across countries and comment on the expected effects over conservatism in earnings, in Section 3 we describe the hypotheses development and research design. Section 4 analyses the results and Section 5 concludes.

(1) We use the term earnings conservatism to refer to the asymmetric timeliness of earnings described by Basu (1997). Other terms used in the literature to identify the same phenomenon are «income statement conservatism», «news-driven conservatism», «ex-post conservatism» or «conditional conservatism». 


\section{INTERNATIONAL ADOPTION OF IASB STANDARDS AND ITS EFFECTS OVER CONSERVATISM IN EARNINGS}

The implementation of IASB standards in different countries responds to different regulatory incentives. In the European Union, IASB standards are compulsory for listed firms, to prepare their consolidated financial statements, from 2005 onwards. Before 2005, the use of IASB standards was allowed in France and Germany. In the EU case, the adoption of the international standards responds to the interest of the European Commission of improving the comparability of accounting information in Europe. The comparability of accounting information is a basic requisite to improve the allocation of rents among competing firms/projects and to improve the efficiency of the internal financial markets. While in the EU comparability is the main objective of introducing international standards, in developing economies the basic interest of using IASB standards is to ensure a certain degree of quality in the information provided through the financial statements, both in terms of relevance and reliability. In both cases, EU and developing countries, another incentive to adopt IASB standards relates to the fact that the SEC (Securities and Exchange Commission, the financial market regulatory body in the US and a member of IOSCO) was expected to accept IASB-compliant financial statements for the purpose of cross-listing in US financial markets.

Looking at the European case, prior evidence suggests that some of the differences in the properties of accounting numbers across European countries are attributable to differential institutional settings that give managers different incentives to reflect in a different way the same economic events in the financial statements. This is especially relevant in the case of conservatism. Differences in the ownership structure, litigation exposure of managers and auditors, shareholder protection mechanisms, etc... lead to pronounced differences in earnings conservatism across countries that the use of a single set of standards will not be able to eliminate if the differences in the institutional context remain and managers' incentives continue to differ.

As earnings conservatism has been pointed out as one of the main source of differences in the properties of earnings across countries, in this study we focus on whether differences in earnings conservatism exist across firms using their own local GAAP or using IASB standards.

\subsection{CONSERVATISM IN EARNINGS}

Conservatism in earnings is a temporary question, and does not imply understating earnings consistently, as the very same accrual principle would prevent this. Basu (1997) defines conservatism in earnings as the asymmetric treatment of gains and losses in the profit and loss account. Losses are recognised on a timelier basis than gains. As Givoly and Hayn (2000) point out, conservatism in the profit and loss account is a question of the timing and sequencing of earnings relative to their associated cash-flows. They argue that, under a steady state, and over a sufficiently long period, accounting based measures of performance will converge to the true economic performance. This argument is similar to the error-cancelling argument in Zhang (2000), where he shows that if there is no growth, accounting earnings asymptotically equal economic earnings ${ }^{(2)}$. Even assuming growth, con-

(2) See analytical demonstration in Zhang (2000, p. 132). 
servatism in earnings will only affect (decrease) the book value of shareholders' equity temporarily (the lags described in Beaver and Ryan, 2000), until the reversal of the accruals.

\subsection{EFFECTS OF THE ADOPTION OF IASB STANDARDS OVER CONSERVATISM IN EARNINGS}

As pointed out in the IASB's conceptual framework (IASC, 1989), the objective of financial statements is to provide information about the financial position, performance and about the changes in the financial position of an enterprise that is useful to a wide range of decision makers in making economic decisions. The IASB's framework describes four qualitative characteristics that accounting information should have to be useful to this wide range of users (investors, lenders, employees, government, etc.): $i$ ) understandability; ii) relevance; iii) reliability, and iv) comparability.

While most developed countries (all EU countries) have accounting systems based on Generally Accepted Accounting Principles similar to the ones stated by the IASB, which lead to relevant and reliable information, firms in developing countries have shifted towards IAS in an attempt to improve the quality of their accounting information. As we already pointed out, the objective of EU countries with the adoption of the IASB standards is to improve comparability. Either in developing countries, or in the European Union, one might expect that given that IASB standards are closer to common-law countries' accounting standards, the adoption of IAS would lead to accounting earnings characteristics, like conservatism, being closer to common-law earnings. However, analysing prior literature (for example, García Lara et al., 2005 for European countries or Ball et al., 2003 for Asian countries) the expectation could be that given that differences in the institutional context do not change and that enforcement (especially in Asian countries) is low, the properties of earnings will not change by using IAS.

Looking at the European Union case, the use of 25 different accounting standards was an obvious barrier to the comparability of accounting information, making it difficult to allocate capital in an efficient way among EU firms. Most local investors used to invest in local firms just because they knew their accounting standards. This situation was undermining the efficiency in the allocation of economic resources and was constraining the range of investment choices of EU citizens. However, prior literature that analyses the international differences in earnings conservatism points out that differences will not disappear just using a set of common standards, as the differences arise because of the different institutional settings. Most of this literature compares common-law accounting regimes (AngloSaxon regimes: US, UK, Ireland) with code-law based countries [all European continental countries $^{(3)}$.

The different role of financial statements in countries with common-law and code-law accounting systems lead to international differences in conservatism (See Ball et al., 2000). In common-law countries (typical examples are the US and the UK), the ownership of the firm is very widespread, and firms seek capital funds directly from small investors through the capital markets. Investors in these countries demand very informative accounting information, and financial statements are the only source of information about the financial affairs of the firm that most of these small investors have. This demand for information is es-

(3) Being The Netherlands a distinctive case in between common-law and code-law based countries. 
pecially important for investors in the case of bad news, as we can assume that they are risk averse. Investors will be willing and able to sue managers and auditors if they fail to disclose bad news on a very timely basis. This enhances the asymmetry in the recognition of good and bad news that the accounting system, per se, already has.

This demand for an asymmetric recognition of good and bad news in earnings (earnings conservatism) is not so important in code-law based countries. In code-law based countries the main providers of capital funds (even through the capital markets) are financial institutions. These financial institutions have other timelier sources of information about the firm than financial statements. They are even represented in the board of directors. Consequently, the demand for earnings conservatism in these countries is lower than in common-law based countries. Banks in code-law based countries demand conservative valuation of assets (balance sheet conservatism), and this more pronounced balance sheet conservative behaviour leads to less asymmetry in the recognition of good and bad news in earnings, that is, to less pronounced earnings conservatism practices (see Pope and Walker, 2003; and Beaver and Ryan, 2005). Other institutional features, for example, the demand for smoothed income streams (see Ball et al., 2000; and Bao and Bao, 2004) will also contribute to less pronounced earnings conservatism in code-law based countries.

Consistent with this explanation of the difference in the demand for earnings conservatism across code and common-law based countries, Ball et al. (2000) and Bushman and Piotroski (2006) find the US more conservative than code-law based countries. In Europe, García Lara et al. (2005) show that the UK is more conservative from a profit and loss account perspective than France and Germany (typical code-law based countries). They show that prior findings of similar levels of earnings conservatism between the UK and European code-law based countries are severely influenced by earnings management practices in Continental European countries.

Bearing in mind this more pronounced earnings conservatism in common-law countries found in prior literature (Ball et al., 2000; García Lara et al., 2005, Bushman and Piotroski, 2006), one might think that by using IASB standards, which are closer to common-law countries' standards (closer to US or UK GAAP), earnings conservatism should increase in code-law based European firms. However, the factors explaining why code-law based firms are more conservative in earnings than common-law based firms relate directly to institutional features in each country (litigation risk, smoothing of earnings due to taxation and dividend policy), and this will not change by using a common set of accounting standards.

Our main objective is, thus, analysing whether the use of the IASB standards will have an effect over earnings conservatism of adopting firms, or if the institutional factors will dominate and determine the properties of earnings regardless of the set of standards that firms use. Our results are consistent with the regulatory change improving the quality of financial reporting only in the presence of strong enforcement and investor protection mechanisms.

\section{RESEARCH DESIGN}

We analyse the effects of IAS implementation in countries with low quality local standards, poor enforcement and corporate governance mechanisms (for example East Asian countries) vs the effects of IAS implementation in countries with high quality local standards and 
better enforcement and governance mechanisms (for example continental European countries).

Given the low relevance and reliability of accounting information from developing countries, for example, East-Asian countries, the use of IASB standards by firms in these countries is expected to contribute to make their accounting information more similar to the one reported by firms in common-law countries. When analysing conservatism, this expectation of increased quality in earnings numbers by using IASB standards should translate into more conservative accounting numbers, that is, a more pronounced asymmetry in earnings caused by bad news being recognised in a timelier basis. However, and as pointed out by Ball et al. (2003), the absence of enforcement mechanisms, together with the use of different and ad-hoc versions of the IASB standards, lead to a decrease in the relevance and reliability of accounting numbers in these countries, which would be making accounting information not timely at all. On the other hand, in countries where a set of high quality accounting standards exist, the use of IAS is expected to maintain a high level of earnings conservatism. This is the case of continental European countries, where earnings conservatism is even expected to increase (from a regulatory point of view) given that most continental European accounting regulations are more conservative from a balance sheet perspective, forcing earnings conservatism measures downwards (see an analysis of the relation between earnings and balance sheet conservatism in Pope and Walker, 2003, and Beaver and Ryan, 2005).

To test these predictions we compare samples of firms using and not using IAS, coming from several country sets: i) common-law countries; ii) code-law countries; iii) European code-law countries; $i v$ ) Emerging countries; $v$ ) Firms using IAS worldwide, and vi) Firms using IAS in Europe. The objective is to see whether there are significant differences in conservatism across the different country sets. We are aware that these sets of countries/firms are very heterogeneous, and that the results are obviously affected by differences in the sample composition.

\section{THE SAMPLE}

The initial sample («IAS sample») to test our first set of analyses consists of 874 firms from 58 countries that adopted voluntarily the IASB standards for financial reporting purposes over the period 1994-2003. The sample is drawn from Compustat Global, and we identify whether the firm is using IAS through the variable «standard note». For comparative purposes, we also use a sample of firms from 20 developed or emerging countries, which used domestic GAAP during the same period, with a total of 12,057 firms, and 79,052 firm-year observations. We will compare the earnings attributes of firms using IAS with the earnings attributes of groups of firms from common-law, code-law and emerging countries. Table 1 provides a description of the sample composition per country, and Table 2 provides sample descriptive statistics. We group firms according to whether they are domiciled in a common-law, code-law or emerging country, and according to whether the firm uses IAS or local GAAP. The descriptive statistics are consistent with the existence of earnings conservatism in all groups of firms, that is, earnings is negatively skewed in all groups (medians exceed means). Also, we can see that the standard deviation of returns is always larger than the standard deviation of earnings, consistent with the intrinsic characteristics of accounting numbers, less affected by news. These descriptive statistics are consistent with prior research. 
TABle 1

COMPOSITION OF TOTAL SAMPLE

\begin{tabular}{|c|c|c|c|c|c|}
\hline \multirow[b]{2}{*}{ Country } & \multirow[b]{2}{*}{ Classification } & \multicolumn{2}{|c|}{ Local-GAAP } & \multicolumn{2}{|c|}{$I A S$} \\
\hline & & Firms & Observations & Firms & Observations \\
\hline Australia & Common-Law & 376 & 2,035 & 3 & 15 \\
\hline Austria & Code-Law & 28 & 150 & 42 & 241 \\
\hline Belgium & Code-Law & 104 & 567 & 16 & 104 \\
\hline Canada & Common-Law & 468 & 3,472 & & \\
\hline France & Code-Law & 586 & 2,973 & 33 & 237 \\
\hline Germany & Code-Law & 341 & 1,664 & 263 & 1,167 \\
\hline Hong Kong & Emerging & 238 & 1,470 & 1 & 2 \\
\hline Italy & Code-Law & 163 & 672 & 85 & 441 \\
\hline Japan & Code-Law & 3,458 & 24,709 & & \\
\hline Malaysia & Emerging & 821 & 4,254 & 3 & 30 \\
\hline Netherlands & $?$ & 147 & 1,008 & 11 & 44 \\
\hline New Zealand & Common-Law & 66 & 322 & 1 & 4 \\
\hline Singapore & Emerging & 447 & 1,976 & 2 & 3 \\
\hline South Africa & Common-Law & 88 & 516 & 18 & 135 \\
\hline Spain & Code-Law & 132 & 802 & 2 & 6 \\
\hline Switzerland & Code-Law & 108 & 491 & 129 & 787 \\
\hline Taiwan & Emerging & 234 & 1,061 & & \\
\hline Thailand & Emerging & 361 & 2,051 & 1 & 10 \\
\hline United Kingdom & Common-Law & 1,145 & 6,889 & 4 & 9 \\
\hline United States & Common-Law & 2,746 & 21,970 & & \\
\hline Other countries $(38)$ & & & & 260 & 1,166 \\
\hline TOTAL & & 12,057 & 79,052 & 874 & 4,401 \\
\hline
\end{tabular}

TABLE 2

DEscriPTIVE STATISTICS: TOTAL SAMPLE

\begin{tabular}{|c|c|c|c|c|}
\hline & & LOCAL-GAAP & & IAS \\
\hline & Code-Law & Common-Law & Emerging & \\
\hline$X_{i t}$ & & & & \\
\hline Mean & 0,02 & 0,03 & $-0,02$ & 0,02 \\
\hline Median & 0,03 & 0,05 & 0,04 & 0,05 \\
\hline St. Deviation & 0,11 & 0,19 & 0,34 & 0,22 \\
\hline Number Obs & 31,415 & 34,664 & 10,663 & 4,330 \\
\hline$R_{i t}$ & & & & \\
\hline Mean & $-0,01$ & 0,16 & 0,10 & 0,11 \\
\hline Median & $-0,06$ & 0,07 & $-0,03$ & 0,03 \\
\hline St. Deviation & 0,38 & 0,63 & 0,67 & 0,57 \\
\hline Number Obs. & 33,105 & 37,360 & 11,971 & 4,796 \\
\hline
\end{tabular}

Notes:

For each firm $i$ and fiscal year $t, X_{i t}$ denotes annual earnings per share before extraordinary items deflated by beginning of fiscal year price; $R_{i t}$ denotes security return over the fiscal year. The top and bottom percentiles of $X_{i t}$ and $R_{i t}$ are excluded, as well as observations with missing values. 


\section{Conservatism TESTS}

To measure the level of earnings conservatism we use stock returns as a proxy for news, and estimate the model proposed by Basu (1997):

$$
X_{i t}=\beta_{0}+\beta_{1} R D_{i t}+\beta_{2} R_{i t}+\beta_{3} R_{i t} R D_{i t}+\varepsilon_{i t}
$$

where: $X$ is earnings per share deflated by share price at the beginning of the fiscal year $t$, $R$ is the rate of return (inclusive of dividends) over the fiscal year $t$, and $R D$ is a dummy variable that takes value 1 in case of bad news (negative or zero rate of return), and 0 otherwise. We use different definitions of earnings (before and after extraordinary and special items); and returns (measured using a 12 month window over the fiscal year, over a 12 month window finishing 3 months after the balance sheet date, and using 15 month windows covering the fiscal year plus 3 months) ${ }^{(4)}$.

We estimate equation [1] for each accounting system from a pooled cross-section (across firms) and time-series (fiscal years) regression. The coefficient $\beta_{2}$ measures the average contemporaneous sensitivity of accounting earnings reported by firms in each group to positive changes in market value of equity (economic gains). The coefficient $\beta_{3}$ measures the incremental response of accounting earnings to negative changes in market value of equity (economic losses). The total response or sensitivity of accounting earnings to negative changes in market value of equity is measured by $\left(\beta_{2}+\beta_{3}\right)$. Following Giner and Rees (2001), we estimate whether the conservatism coefficient $\left(\beta_{3}\right)$ is significantly different across the different groups as:

$$
\left[\phi_{1}-\phi_{2} \mid \sqrt{\sigma_{1}^{2}+\sigma_{2}^{2}}\right] t
$$

where $\phi_{i}$ is the estimated coefficient and $\sigma_{i}$ the standard error for variable $i$.

\section{RESULTS}

Table 3 presents the results of running Equation [1] for six different groups:

i) Firms in common-law countries using their own local GAAP (Australia, Canada, New Zealand, South Africa, United Kingdom and United States).

ii) Firms in code-law countries using their own local GAAP (Austria, Belgium, France, Germany, Italy, Japan, Spain and Switzerland) ${ }^{(5)}$.

iii) As in (ii) but excluding Japan. That is, only European code-law firms.

iv) Firms in emerging countries using local GAAP (Hong Kong, Malaysia, Singapore, Taiwan and Thailand).

(4) There is an ongoing debate (started with the paper by Dietrich, Muller and Riedl, 2007) on whether the Basu (1997) regression offers unbiased measures of earnings conservatism. Ryan (2006) argues that the biases (if any) are small, and Ball and Kothari (2007) analytically demonstrate the validity of the Basu specification.

(5) In a sensitivity test we replicate this analysis including The Netherlands in the code-law based group. The Netherlands can be considered as a hybrid accounting system in between code-law and common-law systems. It is based on the microeconomic theory and although traditionally considered as closer to common-law regimes (see Nobes, 1983), results from prior international studies on earnings conservatism for Dutch firms describe them as closer to code-law firms' countries (see for example García Lara and Mora, 2004). 
v) All firms using IAS identified in Compustat Global (58 countries).

vi) Firms using IAS in our European main sample (Austria, Belgium, France, Germany, Italy, Spain and Switzerland).

\section{TABLE 3}

COMPARISON OF EARNINGS CONSERVATISM ACROSS GROUPS OF FIRMS COMING FROM DIFFERENT ACCOUNTING REGIMES AND USING DIFFERENT ACCOUNTING STANDARDS

\begin{tabular}{|lcccccc|}
\hline Sample & $\beta_{0}$ & $\beta_{1}$ & $\beta_{2}$ & $\beta_{3}$ & Adj. $R^{2}(\%)$ & $N$ \\
\hline Common-Law & 0.05 & -0.00 & -0.02 & 0.30 & \multirow{2}{*}{ (\%) } & \multirow{2}{*}{33,927} \\
& $(33.53)$ & $(-1.66)$ & $(-8.05)$ & $(33.92)$ & & \\
Code-Law & 0.04 & -0.01 & 0.03 & 0.08 & & \\
& $(27.82)$ & $(-4.54)$ & $(8.69)$ & $(13.27)$ & 6.31 & 30,817 \\
Code-Law excluding Japan & 0.06 & -0.00 & 0.01 & 0.24 & & \\
& $(23.18)$ & $(-0.63)$ & $(1.67)$ & $(15.43)$ & 13.02 & 6,828 \\
Emerging countries & 0.02 & -0.03 & 0.03 & 0.15 & & \\
& $(4.05)$ & $(-3.18)$ & $(2.81)$ & $(6.91)$ & 3.75 & 10,455 \\
IAS & 0.06 & 0.01 & 0.00 & 0.03 & & \\
& $(11.03)$ & $(0.53)$ & $(0.07)$ & $(11.68)$ & 10.43 & 4,241 \\
IAS-Europe & 0.06 & 0.01 & -0.02 & 0.39 & & \\
& $(9.23)$ & $(0.47)$ & $(-1.20)$ & $(11.84)$ & 13.24 & 2,931 \\
\hline
\end{tabular}

Notes:

Sample: Firms adopting IAS during the period 1994-2003 are aggregated into the «IAS» sample. The «IAS-Europe» subsample only includes firms from Austria, Belgium, France, Germany, Italy, Spain, and Switzerland.

Firms from countries adopting their domestic standards during the same period are included into three benchmark accounting systems: a) «Common-Law» (Australia, Canada, New Zealand, South Africa, UK, and USA); $b$ ) «Code-Law» (Austria, Belgium, France, Germany, Italy, Japan, Spain, and Switzerland); and c) «Emerging» (Hong Kong, Malaysia, Singapore, Taiwan, and Thailand).

Model:

$X_{i t}=\beta_{0}+\beta_{1} R D_{i t}+\beta_{2} R_{i t}+\beta_{3} R_{i t} R D_{i t}+\varepsilon_{i t}$

For each firm $i$ and fiscal year $t$. $X_{i t}$ denotes annual earnings per share before extraordinary items deflated by beginning of fiscal year price; $R_{i t}$ denotes security return over the fiscal year; and $R D_{i t}=1$ if $R_{i t}<0$ (market value decrease over the fiscal year) and $=0$ otherwise (market value increase).

$N$ denotes the number of firm-year observations available for each accounting system. The top and bottom percentiles of $X_{i t}$ and $R_{i t}$ are excluded.

Analysis: Statistics are from regressions using the pooled cross-section and time-series of firm-year observations for each sample. To control for heteroskedasticity, reported t-statistics in brackets are calculated using the White (1980) variance-covariance matrix.

The results show that for the common-law group (group $i$ ) results are consistent with prior research. Conservatism exists — earnings are clearly asymmetric, $\beta_{3}$ equals 0.30 - and the good news coefficient $\left(\beta_{2}\right)$ is close to zero ${ }^{(6)}$. The intercept is positive and significant, showing the effect of prior period good news. If we focus on the code-law group (ii), we see that results are dominated by Japanese firms. As in Ball et al. (2000) Japan is much less conservative than common-law countries. In our sample, the conservatism coefficient $\beta_{3}$ for the code-law sample including Japan is 0.08 , and the difference with the $\beta_{3}$ coefficient from common-law coun-

(6) The $\beta_{2}$ coefficient is, as expected, very close to zero. However, it is surprisingly negative. This is due to the existence of extreme observations that are not discarded with the typical outlier removal of the top and bottom percentile of each variable. We replicate this test removing more outliers $\left(2 \%, 5 \%\right.$, and the $\beta_{2}$ coefficient becomes positive). 
tries is significanty different ( $t$-stat: 20.55). If we drop Japan from the code-law sample (group iii), we see that the $\beta_{3}$ coefficient rises to 0.24 . This is consistent with prior evidence on European countries (Giner and Rees, 2001, García Lara and Mora, 2004, Bushman and Piotroski, 2006), but we should note that the difference with the common-law firms is still significant ( $t$ stat 2.93). García Lara et al. (2005) argue that the measures of conservatism in European code-law based countries are inflated due to earnings management practices that purposefully decrease earnings for tax and dividend policy reasons. For the two code-law samples the good news coefficient is positive and close to zero, and the intercepts are significant.

Looking at the emerging countries using their own local GAAP (sample iv), the results show that these firms are also significantly ( $t$-stat 6.40$)$ less conservative than firms in commonlaw based countries. The very low coefficient of determination may also be pointing at a very low relevance of accounting numbers in these countries, which is consistent with the results in Ball et al. (2003).

Finally, with regards to the two IAS samples, sample (v) for all countries, and sample (vii) for European countries, we find the following. When we use all firms using IASB standards, results are difficult to interpret due to the tremendous firm heterogeneity, although given that we find very low $\beta_{2}$ and $\beta_{3}$ coefficients we might think that the lack of enforcement in most countries lead to low relevance and low reliability of accounting information. If we focus on European firms using IAS the interpretation is much clearer. We observe a significant increase in the $\beta_{3}$ coefficient ( $t$-stat: 4.50) with respect to firms from the same countries using local GAAP. This increase could be attributable to IASB standards (IAS 16) being less balance sheet conservative than local European continental GAAPs and, consequently, leading to more conservative earnings numbers (see Beaver and Ryan, 2005). Also, European firms using IAS might be listed in other markets, more widely held, and subject to pressures other than those from the European continental institutional context (see Raonic et al. 2004).

In addition, we test if the conservative measures derived from model [1] for the IAS sample are significantly different before and after the adoption of the IAS, by running the following regression:

$$
\begin{aligned}
& X_{i t}=\beta_{0}+\beta_{0 D} D I_{i t}+\beta_{1} R D_{i t}+\beta_{1 D} R D_{i t} D I_{i t}+\beta_{2} R_{i t}+ \\
& \quad+\beta_{2} D R_{i t} D I_{i t}+\beta_{3} R_{i t} R D_{i t}+\beta_{3 D} R_{i t} R D_{i t} D I_{i t}+\varepsilon_{i t}
\end{aligned}
$$

where $D I_{i t}=1$ when accounting earnings of firm $\mathrm{i}$ in fiscal year $\mathrm{t}$ is reported under IAS, and $D I_{i t}=0$ when domestic GAAP were used. Model (3) is separately estimated over the IAS subsample formed by retaining firms from the seven continental European (code-law) countries, and over the IAS subsample that puts together firms from the rest of the world. Table 4 displays the results. While for the European sample we observe that the $\beta_{3 \mathrm{D}}$ coefficient of $0.12(t=2.18)$ confirms a significant increase in the contemporaneous earnings response to bad news when the IASB standards are adopted, when we look at firms from other countries we see that the $\beta_{3 \mathrm{D}}$ coefficient is not significant. Therefore, we cannot conclude that the adoption of IAS in non-European countries over our sample period implies an increase in earnings conservatism. 


\section{TABLE 4}

COMPARATIVE ASYMMETRY IN THE CONTEMPORANEOUS ASSOCIATION BETWEEN EARNINGS AND RETURNS BEFORE AND AFTER THE IAS ADOPTION

\begin{tabular}{|lcccccc|}
\cline { 2 - 7 } \multicolumn{1}{c|}{} & $\beta_{2}$ & $\beta_{20}$ & $\beta_{3}$ & $\beta_{30}$ & Adj. $R^{2}(\%)$ & $N$ \\
\hline European countries & 0.05 & -0.04 & 0.17 & 0.12 & \multirow{2}{*}{ (\%) } & 2,811 \\
& $(2.64)$ & $(-1.63)$ & $(3.87)$ & $(2.18)$ & & \\
Other & 0.02 & 0.03 & 0.24 & -0.09 & 9.06 & 1,417 \\
Countries & $(0.45)$ & $(0.61)$ & $(3.58)$ & $(-1.10)$ & & \\
\hline
\end{tabular}

Notes:

Sample: Firms adopting IAS during the period 1994-2003 are aggregated into two subsamples: firms from 7 continental European countries (Austria, Belgium, France, Germany, Italy, Spain, and Switzerland), and firms from other countries.

Model:

$X_{i t}=\beta_{0}+\beta_{0 D} D l_{i t}+\beta_{1} R D_{i t}+\beta_{10} R D_{i t} D l_{i t}+\beta_{2} R_{i t}+\beta_{2} D R_{i t} D l_{i t}+\beta_{3} R_{i t} R d_{i t}+\beta_{3} D R_{i t} R D_{i t} D l_{i t}+\varepsilon_{i t}$

For each firm $i$ and fiscal year $t$. $X_{i t}$ denotes annual earnings per share before extraordinary items deflated by beginning of fiscal year price, Rit denotes security return over the fiscal year; $R D_{i t}=1$ if $R_{i t}<0$ (market value decrease over the fiscal year) and $=0$ otherwise (market value increase); and $D I_{i t}=1$ when accounting earnings is reported under the IAS and $=0$ under domestic GAAP.

$N$ denotes the number of firm-year observations available. The top and bottom percentiles of XPit and Rit are excluded, as well as observations with missing values.

Analysis: Statistics are from regressions using the pooled cross-section and time-series of firm-year observations for each subsample. Results are not reported for the intercepts. To control for heteroskedasticity, reported t-statistics in brackets are calculated using the White (1980) variance-covariance matrix.

\section{SENSITIVITY TESTS}

To confirm the robustness of our results we replicate our main tests using different definitions of returns. In our main tests we calculate returns over the fiscal year. We also calculate them over a 12-month-window finishing 3 months after the fiscal year end, and over a 15 month window finishing 3 months after the fiscal year. Results are not sensitive to these different definitions of returns.

In our main tests we use earnings before extraordinary and special items. However, and following Pope and Walker (1999), we replicate our tests with bottom-line earnings, as managers might use extraordinary and special items differently in different accounting regimes, especially to avoid capturing bad news in the profit and loss account through ordinary earnings. Using bottom-line earnings our results do not change qualitatively.

We also use Fama and MacBeth (1973) mean annual regressions to avoid our results being driven by cross-sectional dependence problems. Although the results are similar to the ones reported with the pooled samples, we choose to report the pooled results as we have serious concerns about the robustness of mean annual regressions for our samples. The number of observations in the early years of most of our samples (especially the IAS ones) is very limited, which prevents running robust regressions. For most of the samples we only have 7 years of data to run the Basu tests, which puts into question the assumption of normality of the parameters obtained from Fama and MacBeth (1973) mean annual regressions. Also, and as pointed out by Basu (1999), Fama and MacBeth regressions assume stationary parameters, and as we know, some of the accounting regimes under study have changed significantly over the last years. Thus, assuming that the parameters are stationary is questionable.

We also control for differences in the market to book ratio and size, as a first control for differences in economic characteristics and sample composition across the different groups. 
The results of these tests are consistent with prior research. As expected, firms with high market to book ratios (firms that understate more assets, with more balance sheet conservatism) are less conservative in earnings. Also, small firms are more earnings conservative than large firms. This is consistent with prior research, but relatively surprising. Basu (2001) explains this surprising result on the grounds of smaller firms being riskier and facing larger litigation risk. García Lara et al. (2005) also argue that smaller firms in continental European countries engage more in income decreasing earnings management that increase the measures of earnings conservatism. Results of comparisons of conservatism between groups of firms using or not IAS across subsamples of size and the market to book ratio are consistent with the results described for the full sample.

\section{SUMMARY AND CONCLUSIONS}

In this study we analyse whether the use of IASB standards affects the conservatism of earnings of the firms that adopt them. We compare the conservatism of firms by groups of firms/countries using or not IAS. Our results show that the use of IAS in non-European countries does not yield timely accounting numbers (untimely good and bad news recognition in earnings). This result confirms prior evidence by Ball et al. (2003) that the lack of enforcement mechanisms and investor protection mechanisms hinder the quality of accounting information even if accounting standards are considered as high quality. This suggests emerging countries should improve their enforcement mechanisms, as the adoption of IASB standards is not enough, per se, to increase accounting quality.

\section{REFERENCES}

Ahmed, A., Biluings, B., Morton, R., and Stanford-Harris, M. 2002. The role of accounting conservatism in mitigating bondholder-shareholder conflicts over dividend policy and in reducing debt costs, The Accounting Review, 77, 867-890.

Ahmed, A., and Duellman, S. 2007. Evidence on the role of accounting conservatism in corporate governance, Journal of Accounting and Economics, 43, 411-437.

Ahmed, A., and Duellanan, S. 2008. Evidence on the role of accounting conservatism in monitoring managers' investment decisions, Working paper, Texas A\&M University. Available at SSRN: http://papers. ssrn.com/sol3/papers.cfm?abstract_id=1012347

BALL, R., and Kothari, S. P. 2007. Econometrics of the Basu Asymmetric Timeliness Coefficient and Accounting Conservatism, Working paper, University of Chicago and MIT. Available at SSRN: http://ssrn.com/abstract=999710.

BALL, R., Kothari, S. P., and Robin, A. 2000. The effect of international institutional factors on properties of accounting earnings, Journal of Accounting and Economics, 29, 1-51.

BALL, R., RoBIN, A., and SADKA, G. 2008. Is financial reporting shaped by equity markets or by debt markets? An international study of timeliness and conservatism, Review of Accounting Studies, forthcoming, Available online since January 6, 2008. DOI: 10.1007/s11142-007-9064-x.

BALL, R., RoBin, A., and Wu, J. S. 2003. Incentives versus standards: properties of accounting in four East Asian countries, Journal of Accounting and Economics, 36, 235-270.

BAO, B., and BAO, D. 2004. Income smoothing: earnings quality and firm valuation, Journal of Business, Finance and Accounting, 31(9-10), 1.525-1.557.

BASU, S. 1997. The conservatism principle and the asymmetric timeliness of earnings, Journal of Accounting and Economics, 24, 3-37. 
BASU, S. 1999. Discussion on international differences in timeliness, conservatism and classification of earnings, Journal of Accounting Research, 37(supplement), 89-99.

Basu, S. 2001. Discussion on the asymmetric recognition of good and bad news in France, Germany and the United Kingdom, Journal of Business Finance and Accounting, 28, 1.285-1.331.

BeAvER, W. H., and Ryan, S. G. 2000. Biases and lags in book value and their effects on the ability of the book-to-market ratio to predict book return on equity, Journal of Accounting Research, 38, 127-148.

BEAVER, W. H., and RYAN, S. G. 2005. Conditional and unconditional conservatism: concepts and modelling, Review of Accounting Studies, 10, 269-309.

BeEkes, W., Pope, P. F., and Young, S. 2004. The link between earnings timeliness, earnings conservatism and board composition: evidence from the UK, Corporate Governance, 12(1), 47-51.

Bushman, R. M., and Piotroski, J. D. 2006. Financial reporting incentives for conservative accounting: The influence of legal and political institutions, Journal of Accounting and Economics, 42, 107-148.

Bushman, R. M., Piotroski, J. D., and Sмгтн, A. J. 2006. Capital allocation and timely accounting recognition of economic losses: International evidence, Working Paper, The University of Chicago.

Dietrich, J. R.; Muller, K. A., and RiedL, E. J. 2007. Asymmetric timeliness tests of accounting conservatism, Review of Accounting Studies, 12, 95-124.

FAма, E., and MaсBEтн, J. 1973. Risk, return and equilibrium: empirical tests, Journal of Political Economy, 81, 607-636.

García Lara, J. M.; García Osma, B., and Mora, A. 2005. The effect of earnings management on the asymmetric timeliness of earnings, Journal of Business, Finance and Accounting, 32(3\&4), 691-726.

García Lara, J. M.; García Osma, B., and Penalva, F. 2007. Board of directors' characteristics and conditional accounting conservatism: Spanish Evidence, European Accounting Review, 16, 727-755.

García Lara, J. M.; García Osma, B., and Penalva, F. 2008a. Accounting conservatism and corporate governance, Review of Accounting Studies, forthcoming, Available online since November 30, 2007. DOI: 10.1007/s11142-007-9060-1.

García Lara, J. M.; García Osma, B., and Penalva, F. 2008b. Cost of equity and accounting conservatism. Working paper, American Accounting Association annual meeting 2007.

García Lara, J. M., and Mora, A. 2003. La incorporación asimétrica de noticias al resultado contable en un contexto europeo: Evidencia empírica, Revista Española de Financiación y Contabilidad, 32, 235-264.

García Lara, J. M., and Mora. A. 2004. Balance sheet versus earnings conservatism in Europe, European Accounting Review, 13, 261-292.

Gassen, J.; Fülbier, R. U., and Selunorn, T. 2006. International differences in conditional conservatism: the role of unconditional conservatism and income smoothing, European Accounting Review, 15, 527-564.

Giner, B., and ReEs, W. 2001. On the asymmetric recognition of good and bad news in France, Germany and the United Kingdom, Journal of Business Finance and Accounting, 28, 1.285-1.331.

Grvoly, D., and HAYN, C. 2000. The changing time-series properties of earnings, cash flows and accruals: Has financial reporting become more conservative? Journal of Accounting and Economics, 29, 287320.

International Accounting Standards Board IASB. 2003. International Accounting Standard 16: Property, Plant and Equipment, Amended December 2005. IASCF, London.

International Accounting Standards Committee IASC. 1989. Framework for the Preparation and Presentation of Financial Statements, London: IASC.

LAFond, R., and WatTs, R. 2008. The information role of conservatism, The Accounting Review, 83, 443-478.

NoBEs, C. W. 1983. A judgmental international classification of financial reporting practices, Journal of Business, Finance and Accounting, 10(1), 1-19. 
POPE, P. F., and WALKER, M. 1999. International differences in the timeliness, conservatism and classification of earnings, Journal of Accounting Research, 37(supplement), 53-87.

POPE, P. F., and WALKER, M. 2003. Ex-ante and ex-post accounting conservatism, asset recognition and asymmetric earnings timeliness, Working paper, Lancaster University and The University of Manchester.

Raonic, I., McLeay, S. J., and Asimakopoulos, I. 2004. The timeliness of income recognition by European companies: an analysis of institutional and market complexity, Journal of Business Finance and Accounting, 31, 115-148.

RYAN, S. G. 2006. Identifying conditional conservatism, European Accounting Review, 15, 511-525.

VANDER BAUwhede, H. 2007. The Impact of Conservatism on the Cost of Debt: Conditional versus Unconditional Conservatism, Working paper, Katholieke Universiteit Leuven.

WhiтE, H. 1980. A heteroskedasticity-consistent covariance matrix estimator and a direct test for heteroskedasticity, Econometrica, 48, 817-838.

ZhANG, X. 2000. Conservative accounting and equity valuation, Journal of Accounting and Economics, 29, 125-149. 